\title{
Obituary
}

\section{James Barrett Jones, MD (June 23, 1924-January 14, 2009)}

\author{
Robert S. Derkash MD
}

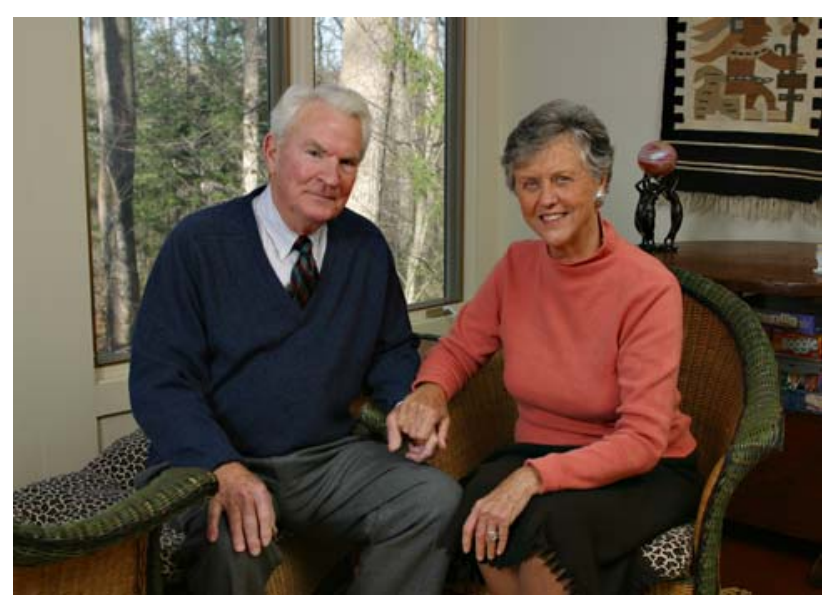

The late James Barrett Jones, MD is seen in this photograph with his wife, Joan Shepherd Jones. (Courtesy of and published with permission from Lynchburg College, Lynchburg, VA.)

Dr. James Barrett Jones (JB) was born in Mt. Sterling, Kentucky on June 23, 1924. He grew up in the South, moving frequently as his father was a minister. He and his four brothers attended numerous schools. He graduated from St. James School in Hagerstown, Maryland in 1941. He received his baccalaureate degree, followed by his MD degree in 1947, from the University of Virginia. He subsequently served his internship at Strong Memorial Hospital in New York, followed by a general surgical residency at New York Post-Graduate Hospital of NYU, and an orthopaedic residency at New York Orthopedic

R. S. Derkash $(\bowtie)$

622 19th Street, Suite 201, Glenwood Springs, CO 81601, USA

e-mail: rderkash@hotmail.com
Hospital of Columbia at Presbyterian Medical Center. He served in the United States Air Force from 1955 to 1957 at the Barksdale Air Force Base in Shreveport, Louisiana, where he was chief of orthopaedic surgery. He was certified by the American Board of Orthopaedic Surgery in 1957.

Thirty-two of the 42 years he practiced orthopaedic surgery were served in Lynchburg, Virginia, where he was chief of staff at Lynchburg General-Marshal Lodge Hospital. He also was a member of the Executive Staff of Virginia Baptist Hospital.

JB was active in his local medical community and was president of the Lynchburg Academy of Medicine from 1978 until 1979, a member of the Virginia State Orthopaedic Society, The American Medical Association, The Russell Hibbs Society, and SICOT (Société Internationale de Chirurgie Orthopédique et de Traumatologie). He also was a member of and Counselor to the Medical Society of Virginia.

One of JBs great loves and interests was the Association of Bone and Joint Surgeons. He was president of the Association in 1980 and served as historian for 7 years. He was on the editorial board of Clinical Orthopaedics and Related Research, a journal he much loved and enjoyed. $\mathrm{He}$ was active in Association meetings.

After retirement, he volunteered with Meals on Wheels, and for more than 5 years, he also volunteered at the free clinic in Lynchburg. He was a strong community supporter and a member of numerous organizations including the United Way and Planned Parenthood. He also was an avid supporter of Opera on the James, an organization in Central Virginia that promotes appreciation and enjoyment of opera via education and community awareness.

JB was a family man who is survived by Joan Shepherd Jones, his wife of 58 years; sons J. Barrett Jones and his 
wife, Kathryn Blair Logwood Jones, and Carleton Shepherd Jones and his wife, Robin Killeen Jones; daughter Susan Pettit Jones Randolph and her husband, Richard Fitz Randolph. He is survived by grandchildren Barrett and Ashley Hightower, and Lillian, Henry, Emily, Arden, Robert, Michael, and Calloway Jones. He also is survived by nieces, Sheila Jones Robbins, Marsha Jones Sample,
Harriett Jones Larsen, Isabel Jones Pencola, and nephew, Fielding Jones.

JB was much involved with his family and his community, and even after retirement, his interest in orthopaedics and this journal never wavered or diminished. He was always interested in the latest innovation or procedure.

He will be strongly missed by everyone who knew him. 